TEME, г. XLIV, бр. 4, октобар - децембар 2020, стр. 1369-1389

\begin{tabular}{lr}
\hline \hline Претходно саопштење & https://doi.org/10.22190/TEME190513081M \\
Примљено: 13. 5. 2019. & UDK 005.96:005.35 \\
Ревидирана верзија: 26. 4. 2020. & $336.76(497.111)$ \\
Одобрено за штампу: 1.12 .2020$. & 657.6
\end{tabular}

\title{
ANALYSING THE LINK BETWEEN CSR REPORTING AND FINANCIAL PERFORMANCE VARIABLES OF BELGRADE STOCK EXCHANGE COMPANIES
}

\author{
Mirjana Mijoković*, Goranka Knežević, Vule Mizdraković \\ Singidunum University, Belgrade, Serbia \\ mirjana.mijokovic.12@singimail.rs
}

\begin{abstract}
Corporate Social Responsibility (CSR) reporting has been subject of various discussions of academicians and accounting practitioners. Although the importance of CRS reporting is not under question, the quality of disclosed non-financial information is still under review. In the light of the new Serbian Law on Accounting (Official Gazette of the Republic of Serbia 73/2019) and EU Directive 2014/95 requirements regarding nonfinancial information, this article investigates the state of non-financial reporting development in Serbian companies in the pre-EU Directive period in order to give suggestions to policymakers how to establish and structure the implementation of the EU Directive and expected challenges on this path. The current state of development of nonfinancial activities is measured by using content analysis and by creating a non-financial reporting index, namely the CSR index for the Serbian companies listed at Belgrade Stock Exchange. CSR index has been corelated with accounting variables (size of the company, auditor type (non/Big 4), revenue and financial results) in order to get deeper understanding of its value drivers. Serbian companies, listed as large, audited by Big 4 and with better financial performance variables, are companies with the higher value of the CSR index and have a higher quality of non -financial reporting. Big companies can serve as a benchmark for the rest of the companies in the economy, but also those companies will have fewer challenges in the EU non-financial Directive implementation in the post-Directive period. Therefore, Serbian policymakers should focus their attention and implementation procedures on the rest of the economy struggling with the non-financial reporting.
\end{abstract}

Key words: corporate social responsibility, non-financial reporting, financial performance, auditing. 


\title{
АНАЛИЗА ОДНОСА ИЗМЕБУ ДРУШТВЕНО ОДГОВОРНОГ ИЗВЕШТАВАҢА И ФИНАНСИЈСКИХ ПЕРФОРМАНСИ КОМПАНИЈА СА БЕОГРАДСКЕ БЕРЗЕ
}

\author{
Апстракт
}

\begin{abstract}
Квалитет извештавања о корпоративној друштвеној одговорности (КДО) била је предмет честих академских и расправа практичара у рачуноводству. Премда се важност овог концепта у расправама није доводила у питања, квалитет извештавања је често био споран. У светлу имплементације новог Закона о рачуноводству (Сл. гласник РС, бр. 73/2019) и Директиве ЕУ 2014/95 о нефинансијким информацијама, овај чланак потенцира истраживање везано за тренутни степен развоја нефинасијског извештавање српских компанија са Београдске берзе у периоду пре усвајања Директиве и њене транспозиције у закон како би се дали одговарајући предлози доносиоцима закона, као и самим компанијама. Тренутно стање развоја корпоративног друштвене одговорности мерено је коришћењем анализе садржаја и креирањем одговарајућег индекса, који је онда повезан са одговарајућим варијаблама као што су величина компаније, ревизорско мишљење, приходи и финансијски резултат и остале финансијске перформансе. Велике српске компаније чију ревизију су обављали ревизори велике четворке и које имају боље финансијске перформансе имају и вишу вредност индекса корпоративне друштвене одговорности. Велике компаније стога могу да послуже као мерило (енгл. benchmark) за остатак економских ентитета који ће морати да примењују поставке Директиве 2014/95 у периоду након имплементације Директиве у домаће законе и сходно томе обавезности примене. Велике компаније имаће мање изазова у примени захтева Директиве, тако да ће српски законодавац морати да усредсреди своју пажњу на остатак привредних друштава, који ће имати бројне изазове на овом путу.
\end{abstract}

Кључне речи: корпоративна друштвена одговорност, нефинансијско извештавање, финансијске перформансе, ревизија.

\section{INTRODUCTION}

The contemporary development of society requires that the principles of sustainable development should be applied and among them the increased use of alternative materials and sources of energy, as well as recycling as a practice of primary importance. In developed countries (United States and United Kingdom), the obligations of business entities concerning social responsibility are regulated by the legal regulation and non-compliance penalties are very high (Matten \& Moon, 2008).

The EU Commission promotes socially responsible behavior of companies in the EU arena by giving adequate principles and guidelines of responsible behaviour and its reporting. The most important regulation in 2014, aimed at establishing adequate and universal reporting environment in the EU, was published as the EU 2014/95/EU Directive whose goal is to harmonize the specific variations of non-financial reporting cases in EU member states. The Directive focuses on transparency and materiality of corporate non-financial reporting and extending the best practice of reporting within the EU, and by integrating those practices in the education, 
practice and research. The materiality concept is strongly focused in the processes of the Directive 2014/95 implementation, because in the preDirective period many potential users published sustainability reports with the obvious lack of material information and with selective content, pointing only to the positive aspects of their sustainability (Baumuller \& Schaffhauser-Linzatti, 2018). The overload of the information presented in the sustainability reports in pre-Directive period is stressed as a problem as well. Too much information affects their relevance for the users because non-financial information has a multidimensional feature. The other problem in sustainability reporting is that companies which use sustainability reports as a PR vehicle for their business have an influence on the rise of greenwashing (Marquis, et. al, 2016). Greenwashing is the over-reporting of positive aspects of sustainability, creating the impression of transparency, but masking the true performance of the entity. In order to address these issues in Serbia, Law on Accounting (Official Gazette of the Republic of Serbia, 73/2019) was passed in December 2019 and has gone into effect on January 1, 2020. Serbia is a EU candidate country meaning that the Directive 2014/95 should be applied or transposed into national law before the full integration with the EU. That is why Serbian Law on Accounting focuses on non-financial reporting (Paragraf 7, article 37) in order to implement the Directive requirements in the national regulation making them mandatory for companies with more than 500 employees. According to the Article 37 of the above mentioned Law, the non-financial report should include all the necessary details to understand the development of business results and financial structure of the entity which are in the area of environmental reporting, social and human resources, human rights and fight against corruption. The non-financial report should address the following (Law on Accounting, article 37): 1. the business model, 2. business policies used and measures for the implementation of the policies, 3. the results of those measures, 4 . risks, and 5. the key non-financial performance measures.

By providing this regulatory framework, we can discuss the contemporary feature of our research by putting it in specific context. By giving non-financial reporting legal status in the Serbian Law on Accounting, which is necessary for the adequate Directive 2014/95 implementation, more pressure will be placed on companies to comply with the requirements and placing them under the scrutiny of governmental officials. In the afterDirective period, companies will surely change their non-financial reporting strategies. By providing the pre-Directive current state of non-financial reporting strategies used by Serbian entities, and by providing future researchers with the basis for comparison in the after-Directive period in the years to come make this research actual. We chose CSR (corporate social responsibility) as an approximation definition for the non-financial reporting. It was chosen because of its all-inclusive nature stating that 
CSR is "the voluntary integration of companies' social and ecological concerns into their business activities and their relationships with their stakeholders. Being socially responsible means not only fully satisfying the applicable legal obligations but also going beyond and investing 'more' in human capital, the environment, and stakeholder relations" (Green Paper, 2001).

The purpose of this article is to emphasize the stage of development and importance of the implementation of the non-financial reporting principles by the listed Serbian companies. This manuscript is a necessary mean of exchange of the experiences and promotion of a comprehensive approach to environmental protection and CSR activities focusing the challenges on the path of non-financial reporting for the Serbian entities. The basic carrier of environmental protection and sustainable development is knowledge. Knowledge is a significant strategic resource of knowledge management in the most efficient manner, which is the base of the modern business and society development (Šekarić \& Kostić, 2012). Now more than ever, a primary goal and a competitive advantage in business organizations is the knowledge in this field. The former understanding that prioritizes technological solutions without investing in the human factor has led to discrepancies between technological development and environment protection. The only way for businesses to communicate their environmental and societal inclusion and awareness is through financial statements, management reviews and notes. CSR reporting has been included in the company's additional reports in order to increase performance (Mijatov, et al., 2018). It can be presumed that corporate social responsibility information disclosed in the financial statements of companies, especially those listed on the stock exchange, would have a great impact on investors, employees, customers, owners, suppliers, local community; and on the decisions they make. Serbian entities follow different approaches to reporting non-financial information using a variety of different options ranging from overloading to green-washing like many other entities in different countries.

The goal of our research is to establish a link between corporate social responsibility (CSR) as a synonym for the non-financial reporting of Serbian entities with financial performance indicators of the sample companies. This research path is chosen because in the light of new Directive 2014/95, the stage of current development of Serbian CSR reporting among the Belgrade Stock Exchange companies will guide us in giving suggestions to the policymakers for the Directive implementation.

The paper is structured as follows. In the first part the goals and benefits of socially responsible behaviour of business entities from the aspect of environmental protection in the form of literature review will be analysed in more detail with the emphasis on CSR and the financial performance variables relationship. The second part of the paper is devoted to research methodology and the presentation of research results. Finally, we 
will outline the basic conclusions and considerations related to the further direction of the research.

\section{LITERATURE REVIEW}

Firstly, we support the idea of various motivators for CSR reporting by presenting some researches from this field which is then extended to the relationship between CSR reporting and financial performance variables, and papers referring to the Serbian practice of CSR.

According to Lichtenstein, Drumwright \& Braig (2004), both theory and recent research indicate that the socially responsible behaviour of a business entity can positively affect the attitude of consumers towards the corporation. Namely, business entities, as well as customers, benefit from socially responsible business. Although the level of social responsibility differs among countries, an increasing number of countries are sanctioning socially irresponsible behaviour. Economic theory also suggests that CSR activities value can be found based on how it affects the wealth of shareholders with lower taxes (Inger \& Vansant, 2019). So, it seems that companies are not only motivated with legal sanctions to emphasize CSR behaviour and implement those measures, but tax avoidance can also be the motivator. An increasing number of business entities focus on investing in socially responsible business to protect the environment and workers' rights.

The research done by Wagner, Lutz \& Weitz (2009) shows that CSR behaviour of companies is often contrary to their established policies and implemented standards of social responsibility. This research shows that inconsistencies are quite frequent in non-financial reporting and certain external assurance should make it more credible. The quality of nonfinancial reporting, namely CSR and its credibility, is affected by external auditing assurance and this was shown in the research done by Kai and $\mathrm{Wu}$ (2019). Sharma, Sharma \& Litt (2018) point out in their research that the price of auditing services is higher when the external auditing firm is required to place an opinion about the client's environmental aspects in initiatives. The auditing of environmental reports/initiatives seems to be very expensive and is seen as an additional burden on companies.

Researches in which the value of CSR is interrelated with financial performance are quite common in the academic journals.

Cochran and Wood (1984), in one of the first articles, investigate the relationship between corporate social responsibility and financial performance using, for the period, new methodology and improved technique of analysis based on industry specific control groups. According to this research, the average age of corporate asset is highly correlated with social responsibility ranking. Some of the studies focus on specific industry, such as sports industry to associate CSR and financial performance variables 
(Kent \& Lee, 2011). Nelling and Webb (2009), using the time series fixed effects approach, find that the correlation between CSR and financial performance is much weaker than previously thought. They find little evidence of causality between financial performance and narrower measure of social performance focusing on stakeholder management. McWilliams and Siegel (200) confirmed positive, negative and neutral impact of corporate social responsibility on financial performance. They find that previous models of correlation between CSR and financial performance do not take into consideration investment in research and development which are an important factor of firm performance. In the specific region or country, CSR and financial performance measure show different influence. In the ASEAN region there is moderate to strong correlation between CSR and financial performance for the top listed enterprises (Waworuntu, Wantah, \& Rusmanto, 2014). According to Tsoutsoura (2004), the social commitment of the organisation is linked to its financial results. Business entities that adopt the principles of corporate social responsibility are more transparent in business and reduce the risk of bribery and corruption. Profitable business entities have an opportunity to invest heavily in socially responsible business, which provides returns in the long run. Research conducted by Dkhili and Ansi (2012) is focused on the effects of CSR on financial performance of observed entities. The profitability is measured by Return on Assets (ROA) and Return on Equity (ROE). The socially responsible business has positive effects on the productivity of employees and on the increase of financial results.

Indeed, social responsibility is correlated with different financial parameters. It has been documented that financial institutions recognize investments in socially responsible business as a positive indicator for easier loan approval. A study by Goos and Roberts (2011) examines the relationship between corporate social responsibility (CSR) and bank debt. Voluntary disclosure of the CSR information affects the reduction of capital expenditures (Dhaliwal, et.al., 2011). Research by Raza, Ilyas, Rauf \& Qamar (2012) documents that corporate social responsibility and financial performance are interconnected. CSR helps improve employee productivity and human relations. They also provide a way to avoid court suits, consumer boycotts and surrounding scandals (Raza, et al., 2012). Some studies conclude that corporate social responsibility affects the market value of the corporation. There is a study showing that CSR reporting has been influenced by the size of the company, profitability, leverage and age of the firm and board size (Joshi, \& Hyderabad, 2018). The research done by Rodriguez-Fernandez (2016) was aimed at the twoway relationship between social responsibility and financial performance of the Spanish public companies. It was confirmed that investments in socially responsible business lead to improved financial returns (RodriguezFernandez, 2016). Therefore, it can be concluded that investments in 
socially responsible business, among else, increase the value of shares of companies, and hence the value of the company. However, only the disclosure of social responsibility scores was associated with higher levels of firm value, as measured by Tobin's (Taylor et.al, 2018).

Country specific studies of the relationship between CSR and financial performance variables have also been conducted (Fauzi, \& Idris, 2009; Trang, \& Yekini, 2014; Uadiale \& Fagbemi, 2012).

There are also studies focusing on other aspects of CSR influence. A study by Brink, Eller \& Green (2018), shows the relationship between CSR and corporate fraud. Davidson, et al., (2019) pointed out that materialistically oriented CEO of a firm will affect the value and quality of CSR. In those companies, the lower value of CSR and more weaknesses in the reporting system are evident. Interesting research was done to correlate corporate governance structure and CSR disclosure. It shows that higher board independence increases the quality of social disclosures (Dah \& Jizi, 2018).

There are several researches regarding CSR reporting quality conducted by Serbian authors. A paper done by Stojanović-Blab, Blab \& Spasić (2016) shows that Serbian companies have a low and unsatisfactory level of sustainability reporting and it shows to what extent firms are familiar with GRI (Global Reporting Initiative) guidelines.

CSR in Serbia is more focused in the area of non-financial philanthropy and humanitarian activities, and companies consider it important for the business (Mijatović, et al., 2015). The CSR index and its relation with the integrated reporting in Serbia has been in the centre of research conducted by Knežević and Pavlović (2019). These researchers found that the integration of financial and non-financial information in financial and sustainability reports of Serbian companies is at a very low level. Corporate social responsibility reporting has been part of business strategy in Serbian transition economy. Results show that CSR has been part of business activities in various companies but it lacks the relationship with the corporate strategy (Krstić, et.al, 2018).

In conclusion, we can contemplate that listed literature predominantly refers to the developed countries and various types of CSR reporting researches conducted in those countries. Research results are quite vague. Some of the studies find positive and strong influence of CSR on financial performance, but other studies found no influence or weak influence. Obviously, having vague results of research in this area indicates that quality of CSR cannot be adequately measured because of the number of CSR indexes created, and because various country-specific differences influence financial performance measures.

This paper will focus on the Republic of Serbia thus providing an overview of the state of CSR development in Serbian listed companies in the pre-Directive period and we posit the following research question: 
Is the quality of CSR reporting of the incorporated businesses in Serbia linked to their financial performance and the results of operations, and would the results give us the opportunity to shape the current state of CSR development in that sample?

\section{RESEARCH METHODOLOGY}

The research sample consists of 113 out of 312 companies listed on the Belgrade Stock Exchange from different fields of business and industry sectors. Companies from the sample were selected randomly and belong to medium and large companies, which totals to 113 companies. There are 24 large companies in the sample, while 89 belong to mediumsized companies. The methodology applied is the content analysis of reports and information disclosed on sample companies' websites concerning socially responsible business and the environment. The analysis of the obtained data has been performed by using the Statistical Package for Social Sciences program; one of the most frequently used data processing programs today.

Annual reports of the companies are considered as important and reliable sources of information concerning the activities of the company. The analysis of financial statements is one of the most commonly used research methods and we apply it in this study as well to measure financial variables. Besides, content analysis was used in order to measure the amount of CSR information disclosed on the companies' websites. The measurement unit consists of the number of words or sentences related to CSR in the text disclosed on official websites of the companies being monitored. Regarding the calculation and interpretation of the CSR index, business entities are considered as profit-making organisations that generate profit.

The following parameters are collected from the web pages of 113 companies in order to build a CSR index: mission, info on CSR on the homepage, accessibility, social media, code of ethics, social reports, economic dimension, environmental dimension, CSR projects, partnership, certificates and future investments (Montecchia, et al., 2016). In comparison to the methodology explained in the paper by cited authors, the methodology used in this paper differs slightly. The following Likert scale has been developed.

Table 1. The scale used in the research

\begin{tabular}{ll}
\hline 0 & No information \\
1 & Only one sentence \\
2 & Only two sentences \\
3 & Brief introduction (more than 2 sentences) with a very little information \\
4 & Text with plenty of details on the subject \\
5 & Text completely devoted to the subject \\
\hline
\end{tabular}


When the home webpage and additional documents do not contain the text on CSR, the value 0 is assigned (Knežević \& Mijoković, 2017). In other cases, if one or two sentences are written and explained to some extent, the values range from $2-4$. The maximum is 5 , which means that the entire text is dedicated to the subject. Then the sum of all values is calculated. The CSR index for each company is calculated when the total sum of the observed parameters is divided with the maximum total for all variables.

Financial performance variables are measured using the CSR index, EBIT, EBITA, number of employees, net result, total revenue, total assets, price, M-score, debt ratio and capital intensity. Those variables have already been explained (Knežević, et al., 2015).

Table 2. Explanation of financial variables used in the research

\begin{tabular}{ll}
\hline Net result & $\begin{array}{l}\text { The difference between the total revenues and expenses } \\
\text { (including tax) of the company for the reporting period. }\end{array}$ \\
\hline $\begin{array}{l}\text { Average number of } \\
\text { employees }\end{array}$ & $\begin{array}{l}\text { Shows the average number of employees at the end of each } \\
\text { month of reporting period. }\end{array}$ \\
\hline EBIT & $\begin{array}{l}\text { EBIT is usually calculated as the difference between the } \\
\text { sales revenue and sales related expenses. EBIT is very } \\
\text { close to this number when a company does not have } \\
\text { significant items of financial (other than mentioned interest } \\
\text { expense) and other results. }\end{array}$ \\
\hline EBITDA & $\begin{array}{l}\text { This financial indicator is calculated when Depreciation } \\
\text { and Amortisation costs are added to EBIT. }\end{array}$ \\
\hline $\begin{array}{l}\text { Debt to total assets } \\
\text { ratio/Debt ratio }\end{array}$ & $\begin{array}{l}\text { Is calculated when total debt is divided with total assets. } \\
\text { Capital intensity }\end{array}$ \\
$\begin{array}{l}\text { Total asset of the company divided by the sales. It is the } \\
\text { opposite of the turnover ratio. }\end{array}$ \\
\hline \multicolumn{1}{c}{ Source: (Knežević, et al., 2015) }
\end{tabular}

In order to check if there is high probability that sampled entities might go bankrupt, we have selected one indicator created to measure the bankruptcy probability for Serbian business entities, the so-called Mscore (Mizdraković, 2012).

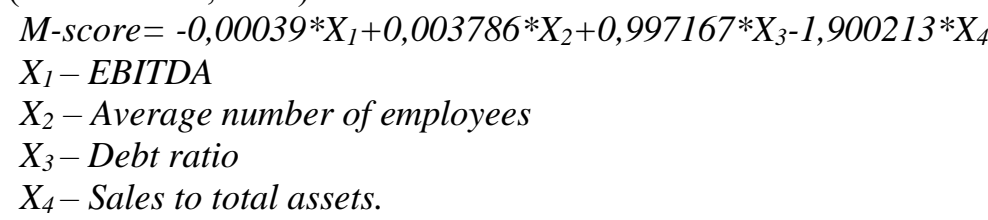

Auditor's opinion variable was marked as follows 0 - Unmodified opinion and unmodified opinion with explanatory remarks, 1 - Qualified opinion, 2 - Disclaimer of opinion, 3 - Adverse opinion. 
Based on the literature review and results we can construct the following hypothesis:

H1: Companies with financial statements audited by Big 4 will show better quality of CSR reporting measured by CSR index.

H2: Companies showing lower probability of bankruptcy have better quality of CSR reporting measured by CSR index.

H3: Companies with better financial performance variables show better quality of CSR reporting measured by CSR index.

In the next section, we will present research results, provide a short discussion and finally recommend future direction of research.

\section{RESEARCH RESULTS}

\section{Descriptive Statistics and Pearson Correlation}

Below are the results of the research conducted for this paper. Descriptive statistics results related to the variable are given in Table 3. The table shows the minimum, the maximum for each variable, followed by the mean and the standard deviation.

Table 3. Results of descriptive statistics*

\begin{tabular}{lrrrrrr}
\hline & $\mathrm{N}$ & \multicolumn{1}{c}{ Minimum } & \multicolumn{1}{c}{ Maximum } & \multicolumn{1}{c}{ Mean } & \multicolumn{1}{c}{ Median } & Std. Deviation \\
\hline Total assets & 113 & $303,192.00$ & $372,211,071.00$ & $6,770,204.09$ & $1,498,322.00$ & $35,119,110.16$ \\
Total revenues & 113 & $78,343.00$ & $247,474,534.00$ & $4,805,846.28$ & $1,091,838.00$ & $23,426,782.75$ \\
EBIT & 113 & .00 & $38,783,895.00$ & $586,211.23$ & $67,135.00$ & $3,672,131.45$ \\
EBITDA & 113 & $4,356.00$ & $70,103,727.00$ & $948,916.53$ & $109,578.00$ & $6,592,805.89$ \\
Net result & 113 & 120.00 & $30,559,237.00$ & $452,571.41$ & $37,019.00$ & $2,894,654.00$ \\
Average number & 113 & 14.00 & $5,043.00$ & 360.98 & 193.00 & 596.72 \\
of employees & & & & & & \\
CSR index & 113 & .00 & .80 & .19 & .14 & .19 \\
Share price & 113 & 70.00 & $58,000.00$ & $5,617.90$ & $1,800.00$ & $8,999.75$ \\
M score & 113 & $-27,322.24$ & -3.36 & -370.27 & -43.00 & $2,569.47$ \\
Debt to total assets & 113 & .01 & 1.00 & .42 & .42 & .25 \\
Capital intensity & 113 & .04 & .97 & .42 & .41 & .21 \\
Auditor opinion type & 113 & .00 & 2.00 & .25 & .00 & .45 \\
Big 4 & 113 & .00 & 1.00 & .16 & .00 & .37 \\
Valid N (listwise) & 113 & & & & & \\
\hline
\end{tabular}

Source: Authors' data

*All values in 000 RSD

According to the results presented in Table 3 for the variable EBIT average value is app. 586.211 and median 67.135 , which shows positively asymmetric distribution. For the EBITDA and Net results average values are higher than the median, which supports the conclusion that the distribution is positively asymmetric. The average value of employees is app. 360 while median is 193 . This leads to the conclusion that, in the sample, a higher number of companies has less than 360 employees. The average number of employees is used as a criterion for the differentiation 
between small, medium sized and large business entities. Therefore, it can be used as a dummy variable for the business entity size, along with the amount of revenues and total assets. The highest standard deviation shows the total asset variable from the sample. The lowest standard deviation is achieved by the CSR index variable of 0.19 . The average debt to total assets is 0.42 with the same median value. This means that the variable distribution is symmetrical and there are no extreme values. The same conclusion can be achieved for the capital intensity value (average value and median of 0.417 ).

According to the results from Table 2, the highest average is 0.25 for the variable auditor's opinion, and the smallest mean is 0.16 for the variable auditing firm. Not a single company from our sample received adverse opinion, which means that the largest number of companies has an unmodified opinion. Most auditor opinions were issued by non-Big 4 auditors.

The results are derived from IBM SPSS 23 statistical software package. The Pearson correlation of CSR index and other variables are presented in Table 4.

Table 4. Pearson coefficient of correlation between CSR and other variables

\begin{tabular}{|c|c|c|c|c|c|c|}
\hline & EBIT & EBITDA & $\begin{array}{l}\text { Number of } \\
\text { employees }\end{array}$ & $\begin{array}{c}\text { Net } \\
\text { result }\end{array}$ & $\begin{array}{c}\text { Total } \\
\text { revenues }\end{array}$ & $\begin{array}{c}\text { Total } \\
\text { assets }\end{array}$ \\
\hline \multirow{2}{*}{ CSR index } & $.216^{*}$ & $.212^{*}$ & $.221^{*}$ & $.209^{*}$ & $.232^{*}$ & $.247^{* *}$ \\
\hline & 0.022 & 0.024 & 0.019 & 0.027 & 0.013 & 0.008 \\
\hline \multirow{2}{*}{ EBIT } & & $.995^{* *}$ & $.762^{* * *}$ & $1.000^{* * *}$ & $.991^{* * *}$ & $.996^{* *}$ \\
\hline & & 0 & 0 & 0 & 0 & 0 \\
\hline \multirow{2}{*}{ EBITDA } & & & $.769^{\text {*** }}$ & $.994^{* * *}$ & $.994^{* *}$ & $.996^{* *}$ \\
\hline & & & 0 & 0 & 0 & 0 \\
\hline \multirow{2}{*}{$\begin{array}{l}\text { Number of } \\
\text { employees }\end{array}$} & & & & $.760^{* * *}$ & $.807^{* *}$ & $.778^{* *}$ \\
\hline & & & & 0 & 0 & 0 \\
\hline \multirow{2}{*}{ Net result } & & & & & $.989^{* *}$ & $.995^{* *}$ \\
\hline & & & & & 0 & 0 \\
\hline \multirow{3}{*}{$\begin{array}{l}\text { Total } \\
\text { revenues }\end{array}$} & & & & & & $.994^{* *}$ \\
\hline & & & & & & 0 \\
\hline & 113 & 113 & 113 & 113 & 113 & 113 \\
\hline
\end{tabular}

Correlation is the quantitative expression of the relationship between variables (Živković, 2015 and Žižić, et al., 2007). In our research, all of the variables have a statistically significant correlation with the CSR index. The highest correlation is achieved by CSR index and total assets (0.25). However, this is not a strong correlation, but it is positive, meaning that companies with more assets or big companies focus more on reporting CSR activities. Also, this correlation is statistically significant (Sig. 0.008), pvalue is lower than 0.05 . The number of employees and the CRS index show statistically significant correlation as well (Sig. 0.02, Corr. 0.22) 
supporting the same hypothesis that big companies are more environmentally and socially sensitive in preparing their non-financial reports and website information.

On the other hand, net result and total revenues show positive, but weak correlation with the CSR index showing that companies with higher revenues and net results put more emphasis on reporting their environmental and social activities.

The following table emphasized the relationship between CSR index and share prices, $\mathrm{M}$ score, debt ratio and capital intensity).

Table 5. Pearson correlation for CSR index and stock prices, M score, debt ratio and capital intensity

\begin{tabular}{|c|c|c|c|c|}
\hline & Share price & M score & Debt ratio & Capital intensity \\
\hline \multirow{2}{*}{ CSR index } & -0.144 & $-.212^{*}$ & -0.032 & -0.117 \\
\hline & 0.127 & 0.024 & 0.738 & 0.216 \\
\hline \multirow{2}{*}{ Share prices } & & 0.018 & -0.156 & -0.066 \\
\hline & & 0.848 & 0.099 & 0.485 \\
\hline \multirow{2}{*}{ M score } & & & -0.027 & -0.031 \\
\hline & & & 0.776 & 0.745 \\
\hline Debt ratio & & & & $\begin{array}{r}-0.083 \\
0.383\end{array}$ \\
\hline
\end{tabular}

CSR index and M score correlation is weak and negative (Corr. 0.21, Sig. 0.02). The lower the M score, the higher the CSR index. The sign of this coefficient is expected because the $M$ score shows that companies are close to the bankruptcy stage. All other variables are correlated with the CSR index and these correlations are weak and negative, but not significant. Companies experiencing higher debt show lower CSR awareness. Companies with more investments in long-term assets (capital intensity) are less sensitive to CSR reporting. Unexpectedly, we find that companies with higher share prices show a lower level of the CSR index. Our country has no developed financial markets, so this result can be due to the underdeveloped stock exchange (the market is illiquid and not deep).

The following table shows the correlation of CSR index and auditing firms.

Table 6. Pearson correlation coefficient for the CSR index and auditing opinion and auditing firm

\begin{tabular}{lcc}
\hline & Opinion & Auditing firm \\
\hline \multirow{2}{*}{ CSR index } & -0.104 & $0.187^{*}$ \\
& 0.273 & 0.047 \\
Auditor opinion & & -0.078 \\
& & 0.411 \\
\hline
\end{tabular}


The coefficient of correlation between auditing firm ( 0 for small firms, 1 is given when auditor is Big 4) is considered to be significant (Sig. 0.047). Although the coefficient shows weak, it implies positive correlation. It means that better CSR reporting is experienced by firms engaging Big 4 auditors. On the other hand, the type of the auditing report is not considered to be correlated with CSR. Whether the report is qualified or unqualified depends on the compliance of clients' financial reports with IFRS, and it has no correlation with CSR reporting.

Model Analysis of CSR Index and M-score and Auditing firms

In this research we tested several regression models. Tables 6-9 show the correlation between the M score and CSR index.

Model 1- CSR index and M score regression analysis

Table 7. Values entered and excluded

\begin{tabular}{|c|c|c|c|}
\hline Model & Variables Entered & Variables Removed & Method \\
\hline 1 & M score & & Enter \\
\hline & $\begin{array}{r}\text { a. Dependent Va } \\
\text { b. All requested } \\
\text { Source: A }\end{array}$ & $\begin{array}{l}\text { iable: CSR index } \\
\text { variables entered. } \\
\text { thors' data }\end{array}$ & \\
\hline
\end{tabular}

Table 8. Model summary

\begin{tabular}{|c|c|c|c|c|}
\hline Model & $\mathrm{R}$ & R Square & Adjusted R Square & Std. Error of the Estimate \\
\hline 1 & $-.212^{\mathrm{a}}$ & .045 & .036 & .181 \\
\hline
\end{tabular}

Table 9. ANOVA ${ }^{a}$

\begin{tabular}{llccccc}
\hline Model & Sum of Squares & df & Mean Square & F & Sig. \\
\hline 1 & Regression & .171 & 1 & .171 & 5.213 & $.024^{\mathrm{b}}$ \\
& Residual & 3.645 & 111 & .033 & & \\
Total & 3.816 & 112 & & \\
\hline \multicolumn{5}{c}{ a. Dependent Variable: CSR index } \\
& b. Predictors: (Constant), M score \\
& Source: Authors' data
\end{tabular}

Table 10. Coefficients

\begin{tabular}{llccccc}
\hline \multirow{2}{*}{ Model } & & \multicolumn{2}{c}{$\begin{array}{c}\text { Unstandardized } \\
\text { Coefficients }\end{array}$} & $\begin{array}{c}\text { Standardized } \\
\text { Coefficients }\end{array}$ & $\mathrm{t}$ & \multirow{2}{*}{ Sig. } \\
\cline { 3 - 5 } & & $\mathrm{B}$ & Std. Error & Beta & & \\
\hline 1 & (Constant) & .185 & .017 & & 10.723 & .000 \\
& M score & $-1.521 \mathrm{E}-5$ & .000 & -.212 & -2.283 & .024 \\
\hline
\end{tabular}

a. Dependent Variable: CSR index

Source: Authors' data 
$\mathrm{R}^{2}$ for the model analysis between the $\mathrm{M}$ score and CSR index shows value of 0.045 (see table 9). It means that $4.5 \%$ of the CSR index variable can be explained by the $\mathrm{M}$ score. Correlation is significant (see table 9) with Sig. 0.024 and F of 5.213. This software also shows the regression line coefficient and Beta and Stand. Error (see Table 10). It can be said that Sig. is lower than 0.05 so the dependent variable has significant influence on the independent.

\section{Model II - Linear regression analysis of CSR index and auditing firm}

The next model tested is the one that shows the relationship between the auditing firm and CSR index.

Table 11. Variables entered and removed

\begin{tabular}{lccc}
\hline Model & Variables Entered & Variables Removed & Method \\
\hline 1 & Auditor type $^{\mathrm{b}}$ & . & Enter \\
\hline
\end{tabular}

a. Dependent Variable: CSR index

b. All requested variables entered. Source: Authors' data

Table 12. Summary

\begin{tabular}{ccccc}
\hline Model & $\mathrm{R}$ & $\mathrm{R}$ Square & Adjusted R Square & Std. Error of the Estimate \\
\hline 1 & $.187^{\mathrm{a}}$ & .035 & .026 & .182146228 \\
\hline \multicolumn{4}{c}{ a. Predictors: (Constant), Revizorska firma } \\
Source: Authors' data
\end{tabular}

Table 13. ANOVA ${ }^{a}$

\begin{tabular}{llccccc}
\hline Model & & Sum of Squares & df & Mean Square & F & Sig. \\
\hline 1 & Regression & .133 & 1 & .133 & 4.017 & $.047^{\mathrm{b}}$ \\
& Residual & 3.683 & 111 & .033 & & \\
& Total & 3.816 & 112 & & & \\
\hline
\end{tabular}

a. Dependent Variable: CSR index

b. Predictors: (Constant), Auditor type

Source: Authors' data

Table 14. Coefficients

\begin{tabular}{llccccc}
\hline \multirow{2}{*}{ Model } & \multicolumn{2}{c}{$\begin{array}{l}\text { Unstandardized } \\
\text { Coefficients }\end{array}$} & \multicolumn{2}{c}{$\begin{array}{c}\text { Standardized } \\
\text { Coefficients }\end{array}$} & \multirow{2}{*}{$\mathrm{t}$} & \multirow{2}{*}{ Sig. } \\
\cline { 2 - 5 } & \multicolumn{2}{c}{$\mathrm{B}$} & Std. Error & Beta & & \\
\hline 1 & (Constant) & .175 & .019 & & 9.385 & .000 \\
& Auditing firm & .094 & .047 & .187 & 2.004 & .047 \\
\hline
\end{tabular}

a. Dependent Variable: CSR index

Source: Authors' data 
$\mathrm{R}$ square is 0.035 meaning that only $3.5 \%$ of the CSR index is explained by the auditing firm engaged. It is statistically significant (Sig. 0.047). ANOVA shows that the F test is 4.017, Sig. 0.047 meaning that the model fits the data. Table 13 shows Beta and Std. Error. The regression line fits the data observed and Sig. is 0.047 while Beta is 0.187 .

\section{Model Analysis of CSR Index and Other Financial Performance Variables}

In the next section, we tested several models of correlation between CSR index and financial performance variables.

\section{Model I - Linear regression of CSR index and compound exposure to the number of employees, net results, revenues, assets, EBIT and EBITDA}

Table 15, 16, 17 and 18 explains this model and how it fits the data.

Table 15. Variables entered and removed

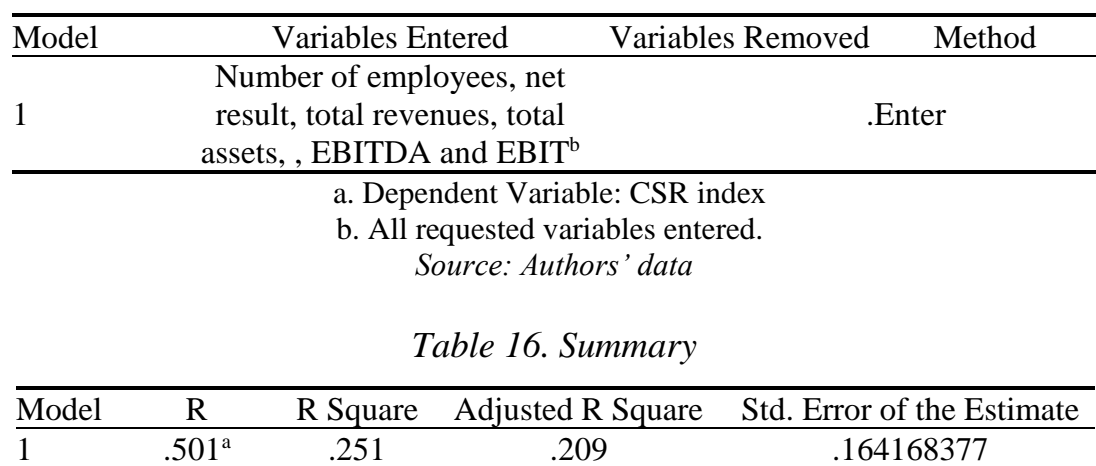

a. Predictors: (Constant), Number of employees, Net result, total revenues, EBITDA, total assets, EBIT

Source: Authors' data

Table 17. ANOVA ${ }^{a}$

\begin{tabular}{llccccc}
\hline Model & & Sum of Squares & df & Mean Square & F & Sig. \\
\hline 1 & Regression & .959 & 6 & .160 & 5.931 & $.000^{\mathrm{b}}$ \\
& Residual & 2.857 & 106 & .027 & & \\
& Total & 3.816 & 112 & & & \\
\hline
\end{tabular}

a. Dependent Variable: CSR index

b. Predictors: (Constant), Number of employees, Net result, Total revenues, EBITDA, Total assets, EBIT

Source: Authors' data

$\mathrm{R}$ square in this model is 0.251 . All of the variables have positive effect on CSR, but it is a weak influence. $25.1 \%$ of CSR index value is 
explained by the number of employees, total assets, total revenues, EBIT, EBITDA and net results. It is a highly significant correlation Sig. $=0.000$. F test is 5.931 meaning that the model fits the data.

Table 18. Coefficients

\begin{tabular}{|c|c|c|c|c|c|}
\hline \multirow[t]{2}{*}{ Model } & \multicolumn{2}{|c|}{$\begin{array}{c}\text { Unstandardized } \\
\text { Coefficients }\end{array}$} & \multirow{2}{*}{$\begin{array}{c}\begin{array}{c}\text { Standardized } \\
\text { Coefficients }\end{array} \\
\text { Beta }\end{array}$} & \multirow[t]{2}{*}{$\mathrm{t}$} & \multirow[t]{2}{*}{ Sig. } \\
\hline & $\mathrm{B}$ & Std. Error & & & \\
\hline 1 (Constant) & .144 & .021 & & 6.997 & .000 \\
\hline Total assets & $2.828 \mathrm{E}-8$ & .000 & 5.381 & 4.095 & .000 \\
\hline Revenues & $-3.361 \mathrm{E}-9$ & .000 & -.427 & -.367 & .714 \\
\hline EBIT & $1.391 \mathrm{E}-7$ & .000 & 2.767 & .623 & .535 \\
\hline EBITDA & $-7.765 \mathrm{E}-8$ & .000 & -2.774 & -2.490 & .014 \\
\hline Net result & $-3.016 \mathrm{E}-7$ & .000 & -4.729 & -1.291 & .200 \\
\hline Number of employees & $-4.746 \mathrm{E}-7$ & .000 & -.002 & -.009 & .993 \\
\hline
\end{tabular}

In Table 18, the very last column shows that only total assets and EBITDA significantly influence the dependent variable.

\section{Model IV - Linear regression of CSR index and Net result, EBITDA and total assets}

Table 19, 20 and 21 explain the model relationship.

Table 19. Variables entered and removed

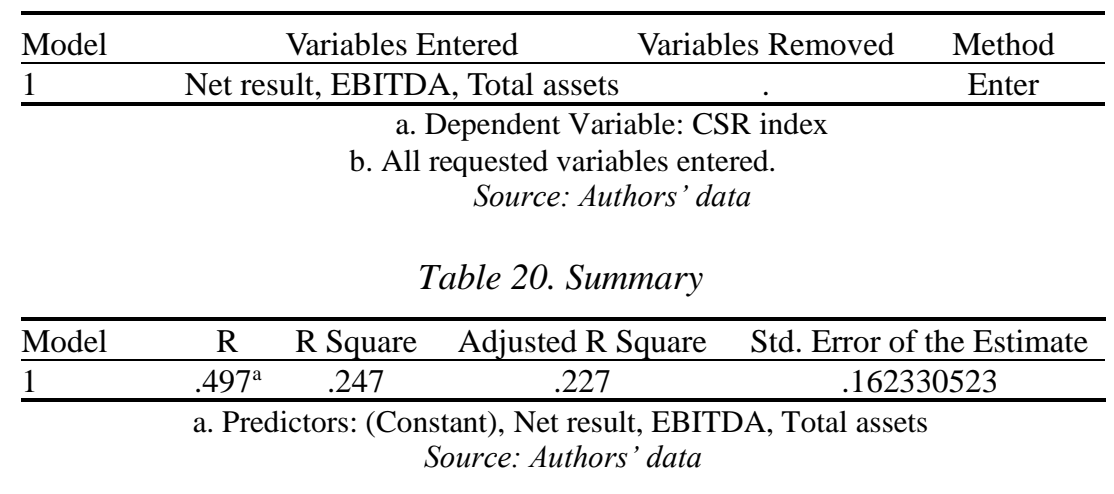


Table 21. ANOVA ${ }^{a}$

\begin{tabular}{llcrccc}
\hline Model & & Sum of Squares & \multicolumn{1}{c}{ df } & Mean Square & F & Sig. \\
\hline 1 & Regression & .944 & 3 & .315 & 11.937 & $.000^{\mathrm{b}}$ \\
& Residual & 2.872 & 109 & .026 & & \\
& Total & 3.816 & 112 & & & \\
\hline
\end{tabular}

a. Dependent Variable: CSR index

b. Predictors: (Constant), Neto result, EBITDA, Total assets

Source: Authors' data

$\mathrm{R}$ square is 0.247 at the level of significance of 0.000 and $\mathrm{F}$ statistics of 11.937 . It means that $24.7 \%$ of the dependent variable (CSR index) has been explained by net results, EBITDA and total assets. The model fits the data.

In the Table 22, the coefficients of regression line are given. All of the variables in the model have significant influence on CSR index (Sig. <0.05).

Table 22. Coefficients

\begin{tabular}{|c|c|c|c|c|c|c|}
\hline & \multirow[t]{2}{*}{ Model } & \multicolumn{2}{|c|}{$\begin{array}{c}\text { Unstandardized } \\
\text { Coefficients }\end{array}$} & \multirow{2}{*}{$\begin{array}{c}\text { Standardized } \\
\text { Coefficients } \\
\text { Beta }\end{array}$} & \multirow[t]{2}{*}{$\mathrm{t}$} & \multirow[t]{2}{*}{ Sig. } \\
\hline & & B & Std. Error & & & \\
\hline \multirow[t]{4}{*}{1} & (Constant) & .140 & .018 & & 7.954 & .000 \\
\hline & Total assets & $2.910 \mathrm{E}-8$ & .000 & 5.536 & 5.409 & .000 \\
\hline & EBITDA & $-8.054 \mathrm{E}-8$ & .000 & -2.877 & -3.015 & .003 \\
\hline & Net result & $-1.555 \mathrm{E}-7$ & .000 & -2.439 & -2.860 & .005 \\
\hline
\end{tabular}

a. Dependent Variable: CSR index

Source: Authors' data

According to our deep analysis, the model IV best explains the CSR index. Total assets or the size of the company quoted at Belgrade Stock exchange, net results and EBITDA are positively correlated with the CSR reporting quality.

\section{CONCLUSION}

The current stage of development of CSR reporting of Belgrade Stock Exchange Companies in pre-Directive 2014/95 period can be regarded as good. It seems that big companies and medium sized companies put adequate emphasis on CSR reporting measured by the CSR index. Big companies from the sample which have better financial performance, especially net income and EBITDA, are more prone to use CSR reporting as a means of communication with stakeholders. Those findings are in line with Dkhili and Ansi, 2012; Raza, Ilyas, Rauf \& Qamar, 2012, and Waworuntu, Wantah, \& Rusmanto, 2014. Our results also show that companies with higher value of assets have better quality of CSR reporting, 
which is in line with the results of Cochran and Wood (1984) whose findings are that average age of corporate assets are in line with better CSR ranking.

Research results show that all three hypotheses are proven to be true. Namely, the CSR index of quoted Serbian companies are significantly correlated with the auditing firm chosen and the M score. Firms with higher M score are closer to bankruptcy so they do not put emphasis on CSR activities (H2 proven). Choosing Big 4 firms is positively correlated with the CSR index meaning that firms whose external auditors are Big 4 firms put more emphasis on relevance and quality of CSR reporting (H1 proven). The combined effects of total assets, net results and EBITDA are positively correlated with CSR (H3 proven). Based on the research results, we can advise Serbian policymakers to prepare the regulatory environment for Serbian companies asking them to report non-financial aspects of business using Directive 2014/95 and Law on Accounting. This regulatory environment should consist of detailed rules for the non-financial reporting in order to overcome future problems of overloading or greenwashing. We also suggest policymakers to pre-emptively set up the prescribed content of this non-financial report or some guidance in order to force companies to report only the information relevant for users, and to make possible the analysis and evaluation of material matters of the CSR aspects of business. Applying these measures would ensure that both the preparers and readers will be provided with improved understanding of the report and its relevant aspects pertaining to the environmental, social and economic impact.

The results of this research do not come without limitations and we will focus on country-specific and time limitations. In terms of countryspecific relations, results can be used and compared with countries from the Balkan region since they share the same economic and transition background, but the same results cannot be used in developed economies.

For future research we recommend academicians to analyse the probability of bankruptcy of companies and its relationship with the CSR reporting several years before the bankruptcy, and to compare these results with the countries from the Balkan region (Croatia, Bosnia and Herzegovina, Slovenia, Macedonia).

\section{REFERENCES}

Baumuller, J. \& Schaffhauser-Linzatti, M. M. (2018). In search of materiality for nonfinancial information - reporting requirements of the Direktive 2014/95/EU. Sustainability Management Forum, 101 - 111. https://www.accountancyeurope. eu/wp-content/NFR-Publication-3-may-revision.pdf.

Brink, A., Eller, K. and Green, K. (2018). The Effects of Corporate Social Responsibility and Wrongdoer Rank on Whistleblowing. Accounting and the Public Interest, 18(1), 104-128. doi:10.2308/apin-52240.

Dah, M. \& Jizi, M. (2018). Board Independence and the Efficacy of Social Reporting. Journal of International Accounting Research, 17(1), 25-45. doi:10.2308/jiar51952. 
Davidson, R. H., Dey, A. and Smith, A., J. (2019). CEO Materialism and Corporate Social Responsibility. The Accounting Review, 101-126. https://doi.org/10.2308/accr52079

Dhaliwal, D., Li, O., Tsane, A., and Yang, Y. (2011). Voluntary Nonfinancial Disclosure and the Cost of Equity Capital: The Initiation of Corporate Social Responsibility Reporting. The Accounting Review, 86(1), 59-100.

Dkhili, H., \& Ansi, H. (2012). The Link between Corporate Social Responsibility and Financial Performance: The Case of the Tunisian Companies. Journal of Organizational Knowledge Management, 2012, 1-11. doi: 10.5171/2012.640106.

EU Commission (2001) Green Paper: Promoting a European Framework for Corporate Social Responsibility, https://ec.europa.eu/transparency/regdoc/rep/1/2001/EN/12001-366-EN-1-0.Pdf

Goos, A., \& Roberts, G. (2011). The impact of corporate social responsibility on the cost of bank loans. Journal of Banking \& Finance, 35(7), 1794-1810.

Halkos, G. \& Skouloudis, A. (2017). Revisiting the relationship between corporate social responsibility and national culture: a quantitative assessment. Management Decision, 55(3), 595-613. doi:https://doi.org/10.1108/MD-12-2016-0868

Inger , K. K. \& Vansant, B. (2019). Market Valuation Consequences of Avoiding Taxes While also Being Socially Responsible. Journal of Management Accounting Research.75-94. https://doi.org/10.2308/jmar-52169

Joshi, G. S. \& Hyderabad, R. L. (2018). Determinants of Corporate Social Responsibility Reporting in India Management a Review. Journal of Management, 6(1), 1-10. http://www.iaeme.com/jom/issues.asp?Jtype=JOM\&VType=6\&IType=1

Kai, D. \& Wu, S. J. (2019). Does external Assurance Enhance the Credibility of CSR Reports? Evidence from CSR - related Misconduct Events in Taiwan. AUDITING: A Journal of Practice \& Theory, 101-130. https://doi.org/10.2308/ajpt-52418

Knežević, G., Stanišić, N., and Mizdraković, V. (2015). Analiza finansijskih izveštaja [Financial Statements Analysis]. Belgrade: Singidunum University.

Knežević, G., \& Mijoković, M. (2017). Sustainability reporting of listed companies on the Belgrade Stock Exchange. Singidunum University International Scientific Conference 'Challenges in modern corporate governance' (30-35). Belgrade: University Singidunum, doi:10.15308/finiz-2017-30-35.

Knežević, G. \& Pavlović, V. (2019), CSR reporting practice:is there room for integration?

Evidence from Serbian foreign investors, Journal of East European Mmanagement Studies,24(2), 280-304, DOI:10.5771/0949-6181-2019-280

Krstić, N., Trbovich, A.,S. and Drašković, A. (2018). Evaluating the strategic approach to CSR in Serbia,TEME, 503-521. doi:10.22190/TEME1802503k

Lichtenstein, D., Drumwright, M., and Braig, B. (2004). The Effect of Corporate Social Responsibility on Customer Donations to Corporate - Supported Nonprofits. Journal of Marketing, 68(4), 16-32.

Matten, D., \& Moon, J. (2008). Implicit and explicit CSR: a conceptual framework for a comparative understanding of corporate social responsibility. Academy of Managament Review, 33(2), 404-424.

Marquis, C., Toffel, M.W. and Zhou, Y. (2016) Scrutiny, norms and selective disclosure: A global study of greenwashing. Organ Sci 27(2):483-504, DOI: 10.1287/orsc. 2015.1039

Mijatović, I., Miladinović, S. and Stokić, D. (2015). Corporate Social Responsibility in Serbia:Between Corporate Philanthropy and Standards, Chapter from book Corporate Social Responsibility in Finland: From Local Movements to Global Responsibility, 333-350. doi: 1007/978-3-319-13566-3_18 
Mijatov, M., Blešić, I., and Dragin, A. (2018). Corporate social responsibility and service orientation of hotel employees. TEME g. XLII br. 2 april-jun 2018, 441-458. doi: 10. 22190/TEME 1802441M.

Mizdraković, V. (2012). Komparativna analiza ekonomskih aspekata stečaja [Comparative analysis of economic aspects of bankruptcy] (PhD Thesis). Retrieved from www.singipedia.com/content/3276-Komparativna-analizaekonomskih-aspekata-ste\%C4\%8Daja.

Montecchia, A., Giordano, F., and Grieco, C. (2016). Comunicating CSR: integrated approach or Selfie? Evidence from the Milan Stock Exchange. Journal of Cleaner Production 136, 42-52.

Naughton, J. P., Wang, C. and Yjeung,. (2019). Investor Sentiment for Corporate Social Performance. The Accounting Review, 401-420. https://doi.org/10.2308/accr52303

Raza, A., Ilyas, I., Rauf, R., and Qamar, R. (2012). Relationship between Corporate Social Responsibility (CSR) and Corporate Financial Performace (CFP): Literature review approach. Elixir Fin. Mgmt. 46, 8404-8409.

Rodriguez-Fernandez, M. (2016). Social responsibility and financial performanse: The role of good corporate governance. BRQ Business Research Quarterly, 19(2), 137-151.

Sharma, D., Sharma, V., and Litt, B. (2018). Environmental Responsibility, External Assurance, and Firm Valuation. AUDITING: A Journal of Practice \& Theory. 37(4), 207-233. doi:10.2308/aipt-51940.

Skouloudis, A. (2015). Revisiting the national crporate social responsibility index, MPRA Munich Personal ReREc Archive, https: //mira.ub.uni-muenchen.de/64864/

Stojanović-Blab, M., Blab, D., and Spasić, D. (2016) Sustainability Reporting - A challenge for Serbian companies, Teme - Journal for Social Science, 40(4), 1349-1366.

Šekarić, M., \& Kostić, M. (2012). Zaštita životne sredine, imperativ tehnološkog razvoja [Environment protection, imperative of technological development]. $X$ International scientific conference Synergy 2012 (218-223). Bijeljina: Synergy University.

Tsoutsoura, M. (2004). Corporate Social Responsibility and Financial Performanse. Uc Berkeley Working Paper Series, 1-22.

Taylor, J., Vithayathil, J., and Yim, D. (2018) . Are Corporate Social Responsibility (CSR) Initiatives such as Sustainable Development and Environmental Policies Value-enhancing or Window Dressing? Forthcoming in :Corporate Social Responsibility and Environmental Management, 1-19.

Wagner, T., Lutz, R., and Weitz, B. (2009). Corporate Hypocrisy: Overcoming the Threat of Inconsistent Corporate Social Responsibility Perceptions. Journal of Marketing, 73(6), 77-91.

Živković, S. (2015). Analiza podataka u SPSS-u: Priručnik iz statistike [Data Analysis in SPSS: Statistics manual]. Podgorica: De Facto Consultancy.

Žižić, M., Lovrić, M., and Pavličić, D. (2007). Metodi statističke analize [Methods of Statistical Analysis]. Belgrade: Faculty of Economics in Belgrade. 


\title{
АНАЛИЗА ОДНОСА ИЗМЕБУ ДРУШТВЕНО ОДГОВОРНОГ ИЗВЕШТАВАЫА И ФИНАНСИЈСКИХ ПЕРФОРМАНСИ КОМПАНИЈА СА БЕОГРАДСКЕ БЕРЗЕ
}

\author{
Мирјана Мијоковић, Горанка Кнежевић, Вуле Миздраковић \\ Универзитет Сингидунум, Београд, Република Србија
}

\begin{abstract}
Резиме
У развијеним земљама (САД и Уједињено Краљевство) обавезе пословних субјеката у погледу друштвене одговорности регулисане су законском регулативом, а казне за неусклађеност су веома високе. Савремени развој друштва захтева да се принципи одрживог развоја примењују и у извештавању привредних ентитета. На основу финансијских извештаја, израчунати су основни финансијски показатељи пословања, а кроз анализу садржаја текста објављеног на интернет страницама компанија везаног за друштвено одговорно пословање измерен је квалитет КДО-а информација објављених на веб-страницама компаније. Анализа добијених података извршена је помоћу статистичког пакета за друштвене науке SPSS. Резултати су показали да постоји позитивна корелација између КДО индекса и укупне имовине и врсте ревизорске фирме, односно да ли ревизорска фирма припада Big4, док постоји негативна корелација између КДО индекса и М скора. Оба резултата су посредно повезана са успешношћу пословања привредног друштва, односно са његовом профитабилношћу. Наиме, када је привредно друштво близу стечаја, није у могућности да води рачуна о друштвено одговорном пословању, па друштвена одговорност опада са порастом вероватноће одласка у стечај. Друштвено одговорно пословање штити и увећава имовину и имиџ привредног друштва, развија и пружа потпору људима засновану на знању, повећава могућност привлачења потребних кадрова, јер се привредно друштво перципира као мање ризично, те оптимизира оперативну ефикасност. Компаније које се листирају на српском тржишту капитала могу очекивати пораст цена акција као награду за своје друштвено одговорно извештавање. У светлу примене Директиве ЕУ 2014/95 о нефинансијском извештавању и њене имплементације коју захтева нови Закон о рачуноводству, ово истраживање и препоруке дате доносиоцу Закона и подзаконских аката може помоћи у бољем структурисању подзаконских аката ради адекватне и оперативније примене законских обавеза проистеклих из поменуте директиве.
\end{abstract}

